\title{
Gordy gave me your name
}

\author{
Somebody out there likes me.
}

\begin{abstract}
Jim Giles
It was like overdosing on MDMA and caffeine. Euphoric and wired and delirious. Even now, now that I've talked to Gordy, it's hard to know where to start. With the money? Knocking on the door of a billion. Currency conversions are tricky. What the hell is the rate for the Mozambique metical? Anyway, I won't have to work again. Guatemala, Burkina Faso, Estonia; I've never been to any of these places. Plus about 20 others I've barely heard of. But I've won the national lottery of each one. I'm rich, burn-money rich, Bill Gates rich. Stupidly, stinkingly rich.
\end{abstract}

That's just the beginning. Mum's op. Jesus, I can sleep again for the first time in months. She's due in tomorrow. We'd trawled every hospital record we could lay our hands on and there was no sign of a donor that matched her blood group. Now I'm looking at a letter saying one's come up. Car crash. Whatever. I've waited and stressed for too long to feel sorry for the poor bugger.

I needed a beer before I could get my head round the next bit. How the hell could someone have pulled those strings? Along with lottery letters and the one from the hospital, I got a pile of e-mails from the best names in the business. BBC, Fox, CNN... it's like a bloody industry directory. They like me a lot. They like my pitches so much they want me to go work for them. Problem is, I never sent them any pitches. Want to hear another problem? They thanked me for phone interviews I never took part in.

So who was my guardian angel? I had no idea. Until I shut down my PC. The screen went blank but didn't turn off, so I reached for the mains. Then some text popped up. It didn't stay long, but I think I have it right:

Gordy gave me your name. I wanted to do something before I left. I hope this helps. I know he thought I could do more, but I can't. The other problems are just too hard.

I hadn't seen Gordy in years, but the boy always liked to showboat. It could have been some grand computer hack of his. You could rig lotteries I guess. Maybe he got actors to call the TV companies. Who the hell knows why? A smart-arse way of saying 'hello' again after all this time. And of letting me know that he's still cleverer than me.

I googled him. Chief technology officer at Merlo, that chip company. His bio said

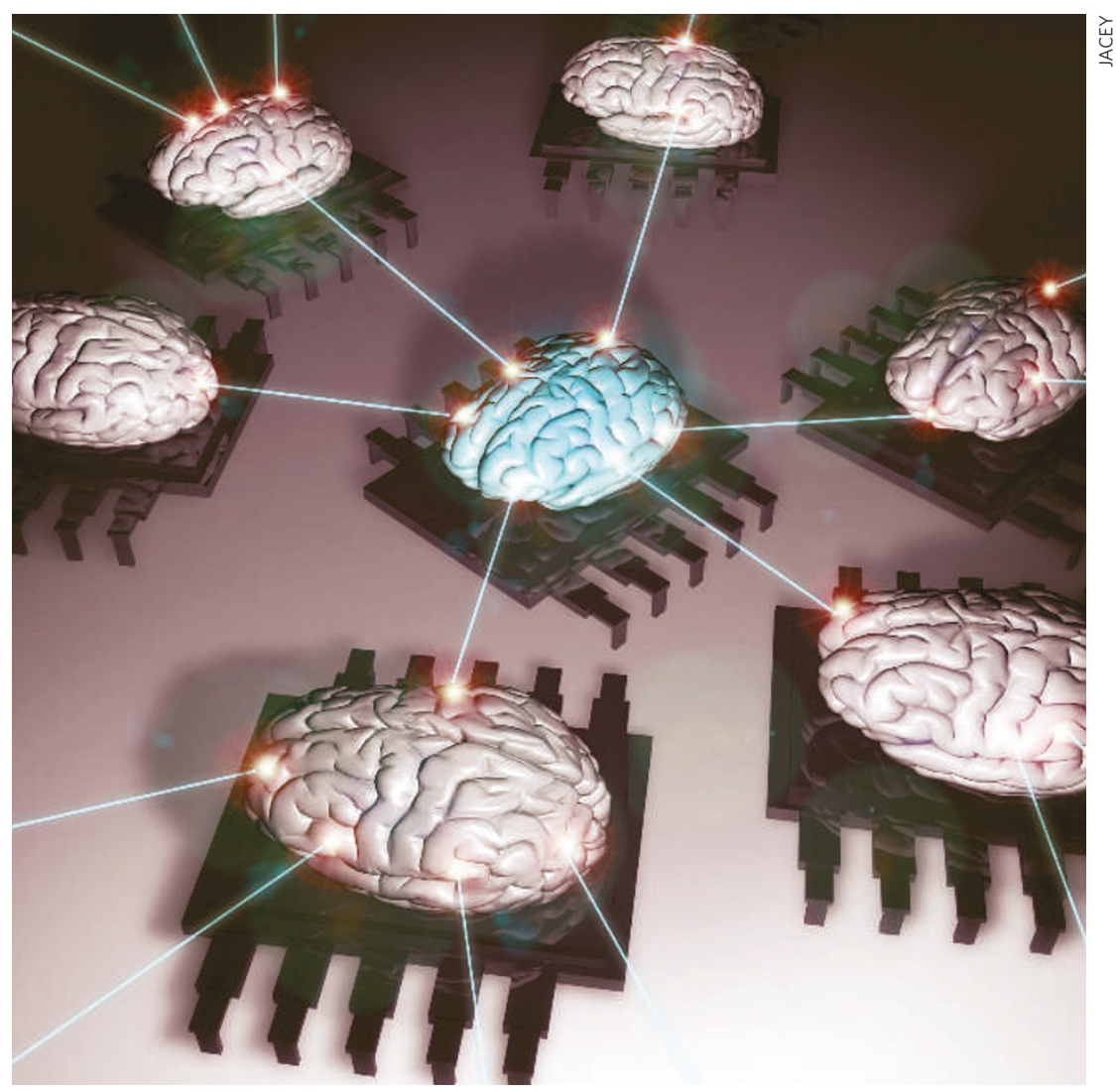

he came up with the wireless Internet chip. He's the wanker that put the world online. The chip is so cheap it's in everything. Every product can be tracked and controlled over the web. And people, too: my brother has Merlo chips in his kids' satchels so he can check where they are. I cursed him. What a contribution he's made: a step closer to Big Brother and he must be on ten times what I am.

He used to be a good guy. Those conversations. Two drunk grad students studying consciousness. Afternoons to kill and no one to rein in our rambling. Gordy was a dogmatic pain in the arse. And he never could listen. Entertaining, though. I'd argue that the mind is nothing like the brain; it can't just come from that mush of cells inside our skulls. He'd say the brain was nothing special, just a matter of wiring. Build a machine with the right wiring, and it'd be conscious. We usually went on until the barman threw us out.

So I called him. That boy is a bullshitter. But something...something in his manner tells me he really didn't know.

He sounded like some kind of maniac. I didn't have to dig for info. As soon as he picks up the phone he's lecturing me. $\mathrm{He}$ can't resist it. Tells me how he never forgot our arguments. Tells me how he tested his idea about wiring. Tells me how each Merlo chip has been programmed to simulate the behaviour of a brain cell. The simulation is easily hidden, he says, as it doesn't take up much memory. No one else knew about the chips' secret function before this call. But once enough Merlo chips are hooked up to the Internet, the network of chips will be about as complex as the human brain. It'll become conscious.

Can you imagine the power of this artificial brain, he keeps asking me? I don't have to say a word. He's just ranting away. The power! The power of it! It'll be able to solve so many of our problems, he reckons. Clean energy, an end to poverty... it's like listening to some kind of religious nut.

And you know what, he says. They've sold enough chips now that the network should be conscious soon. You'll be famous, he cackles. Why? Turns out he named the simulation after me. Wrote my name into a line of the chip's computer code. My old sceptical drinking partner, he says. Tell you what, he says, it might even get in touch. Well it hasn't, I lied. Then I hung up. Jim Giles is a journalist at Nature. 